\title{
Soil Seed Bank and Aboveground Vegetation in Grazing Lands of Southern Marmara, Turkey
}

\author{
Alıngül ÖZASLAN PARLAK, Ahmet GÖKKUŞ, Hasan Can DEMİRAY \\ Department of Field Crops, Agriculture Faculty, Çanakkale Onsekiz Mart University, Çanakkale 17020, \\ Turkey;gulozaslan@yahoo.com,agokkus@yahoo.com,h.can.dmry@hotmail.com
}

\begin{abstract}
The composition and conservation of plant communities is greatly influenced by the soil seed bank. Information on the soil seed banks and the remaining vegetation in these ecosystems is crucial for guiding the restoration efforts. This study examines the size, species richness, diversity, uniformity, and similarity of soil seed banks and aboveground vegetation in 6 different grazing lands including coastal pasture, reseeded pasture, artificial pasture, lowland shrubland, ungrazed pasture, and hillside shrubland. Forty-eight soil samples were taken by cores with a diameter and depth of $10 \mathrm{~cm}$ from each of grazing lands in August of 2007. A vegetation survey was conducted using a $0.5 \times 0.5-\mathrm{m}$ quadrant in both the spring and fall. Eighty species were observed in soil seed banks and aboveground vegetation. The largest seed bank was observed in reseeded pasture $\left(7,715 \mathrm{seed} / \mathrm{m}^{2}\right)$, while the smallest seed bank was found in coastal pasture $\left(2,755 \mathrm{seed} / \mathrm{m}^{2}\right)$. Coastal pasture also possessed the least amount of aboveground vegetation $\left(131\right.$ plants $\left./ \mathrm{m}^{2}\right)$. The most aboveground vegetation was found in ungrazed pasture $\left(155\right.$ plants $\left./ \mathrm{m}^{2}\right)$. The most common species in seed banks were annual and perennial grasses in reseeded pasture, annual forbs in artificial pasture and hillside shrubland, and perennial forbs in low shrubland and ungrazed pasture. Species richness, diversity, and uniformity in seed banks were highest in lowland shrubland and lowest in artificial pasture. The seed bank and aboveground vegetation were similar in ungrazed pasture, coastal pasture, reseeded pasture, low shrubland, hillside shrubland and artificial pasture. Shrublands play an important role in species richness and the number of germinated seeds from seed banks of grazing lands in southern Marmara. The results showed that reseeding or a decrease in grazing pressure may improve the condition of grazing lands
\end{abstract}

Keywords: aboveground vegetation, Mediterranean, soil seed bank, species diversity

\section{Introduction}

Southern Marmara has a Mediterranean climate; thus, shrublands (maquis) are common in the region (Yilmaz, 1993). Shrublands are composed of evergreen and deciduous shrubs and annual or perennial plants. Annuals generally grow in heavily grazed lands on dry, low yielding soils and are the most common vegetation in the Mediterranean (Y1lmaz, 1996; Marcelo et al., 2003). Mediterranean shrubs provide habitats for wildlife (Papachristou et al., 2003) and are an important food source for domestic animals. Throughout the year, shrublands are grazed by sheep and goats. The combination of shrubs and herbaceous plants produce feed in the spring and fall. Goats that graze heavily on shrubs prefer green herbaceous varieties (Papachristou, 1994), and many grazing lands in the Mediterranean are composed entirely of herbaceous plants. The loss of shrubs from grazing land may be due to conversion to farmland, poor soil quality or exploitation. For instance, coastal land is composed of sandy soil with a low water holding capacity that suffers from drought in the summer. Drought resistant therophytes are dominant in these areas (Raunkiaer, 1934). Studies to improve the landscape have been conducted on abandoned lands due to the loss of natural and quality plants from these areas. Reseeding is the best method for improving abandoned areas (Altin et al., 2005), leading to an increase in yield and quality and a decrease in species richness (Bakker, 1989; Tallowin, 1996).

Soil seed banks play an important role in the composition and conservation of plant communities (Grubb, 1977; Leck et al., 1989; Wisheu and Keddy, 1991). The composition of the seed bank depends on the composition and production of current and previous plant communities, as well as the longevity of seeds under local conditions. Seeds that have been brought in from surrounding areas also contribute to the seed bank.

Seed production is dependent on land use and environmental factors: production can be diminished by a reduction in leaf area due to livestock grazing, the allocation of photosynthate to reproductive organs, or by the direct removal of flowers and seeds (Sternberg et al., 2003). Ungrazed sites typically possess a greater number of species and higher species density in the seed bank compared to grazed sites (O'Cannor and Pickett, 1992; Jutila, 1998; Mayor et al., 2003). Navie et al. (1996) found that 
the total seed density in the soil seed bank of Queensland decreased with high levels of grazing and increased with intermediate grazing levels due to an increase in the number of annuals.

On the other hand, soil features (humidity, texture, etc.) determine the composition of vegetation and amount of seeds produced by plants. Due to the prevalence of drought in sandy soils, annual species are common, and the seed number in the seed bank is generally low (Staaf et al., 1987). Alternatively, water resources are not limited in low areas during dry seasons. Perennials are able to grow and produce enough seeds to perpetuate themselves, even under heavy grazing.

Due to deep root systems, shrubs in the Mediterranean region are able to adapt and can provide invaluable food to grazing animals and sustain soil productivity (Bochet et al., 1999). Because shrubs endure under grazing conditions, they also enable the survival of many herbaceous species: perennial herbaceous species can mature under the canopy of shrubs.

There are many studies on the botanical composition, yield (Ozaslan Parlak et al., 2011), and animal performance (Tölü et al., 2007) of grazing lands in southern Marmara. However, studies on seed banks in the region have not been conducted. The objectives of this study were to determine the size, composition, species richness and diversity of the seed bank and aboveground vegetation of different grazing lands representing southern Marmara region and to describe the relationship between the seed bank and existing vegetation within grazing lands.

\section{Materials and methods}

The study was conducted on Çanakkale grazing lands, located in northwest part of Turkey. Çanakkale has a typical Mediterranean climate (Türkeş et al., 2002): the mean annual precipitation is $615.5 \mathrm{~mm}$ and falls mainly in the winter and spring. The rainy season typically begins in October and ends in May, while summers are dry and hot. The mean annual temperature is $15^{\circ} \mathrm{C}$.

Six different grazing lands located in southern Marmara were chosen as study sites, including coastal pasture, reseeded pasture, artificial pasture, low shrubland, ungrazed pasture, and hillside shrubland.

Coastal pasture: The dominant plant species in coastal pasture are annual and perennial grasses including Briza minor, Hordeum marinum marinum, Avena fatua, Poa pratensis, Bromus hordeaceus, Cyperus capitatus. Legumes present in coastal pasture include Medicago marina and Trifolium resupinatum. The soil is sandy, $\mathrm{pH}=7.65, \mathrm{EC}=$ $2.52 \mathrm{dSm}, \mathrm{CaCO}_{3}=4.89 \%$, organic matter $=1.14 \%$, available phosphorus and potassium 8.16, $100.6 \mathrm{mgkg}$ respectively.

Reseeded pasture: Originally, reseeded pastures possessed a large amount of Paliurus spina-christi; however, these plants were removed because they restricted grazing.
Subsequently, the land was reseeded with Lolium perenne, Bromus inermis, Medicago sativa, and Lotus corniculatus in 2005 and fertilized with N and P. Controlled grazing practice are applied in this site. The soils of reseeded pasture are loamy, $\mathrm{pH}=7.27, \mathrm{EC}=0.29 \mathrm{dSm}, \mathrm{CaCO}_{3}=4.29 \%$, organic matter $=5.16 \%$, available phosphorus and potassium 62.80, $469 \mathrm{mg}$ kg respectively.

Artificial pasture: Artificial pasture was tilled after which wheat was grown. An artificial pasture is composed of a mixture of $20 \%$ Medicago sativa, 20\% Lotus corniculatus, 30\% Lolium perenne, and 30\% Bromus inermis. These species are the most common in grazing lands, although other types of herbaceous plants have also been found. Artificial pasture is grazed under controlled conditions. The soil is loamy sand, $\mathrm{pH}=7.38, \mathrm{EC}=0.38 \mathrm{dSm}^{-1}$, $\mathrm{CaCO}_{3}=11.90 \%$, organic matter $=3.98 \%$, available phosphorus and potassium $29.74,394 \mathrm{mg} \mathrm{kg}^{-1}$ respectively.

Lowland shrubland: Low shrubland has been heavily grazed by goats and contains Paliurus spina-christi, Sarcopoterium spinosum, Dactylisglomerata, Poapratensis, Avena barbata, Lolium perenne, Aegilops sp, Trifolium campestre, Plantago sp., and Crepissp. The soil is a slightly alkaline clay loam that is $\mathrm{pH}=7.59, \mathrm{EC}=0.21 \mathrm{dSm}^{-1}, \mathrm{CaCO}_{3}=4.12 \%$, organic matter $=3.51 \%$, available phosphorus and potassium $45.2,205 \mathrm{mg} \mathrm{kg}^{-1}$ respectively.

Ungrazed pasture: Ungrazed pasture is covered with Quercus infectoria, Quercus coccifera, Phillyrea latifolia, and Paliurus spina-christi. Other common species on ungrazed pasture include grasses such as Dactylis glomerata, Lolium perenne, Hordeum spantaneum and Avena clauda legumes such as Trifolium campestre, and other species including Anagallis arvensi, and Crepis zacinta. The soil is sandy loam that is $\mathrm{pH}=7.06, \mathrm{EC}=0.42 \mathrm{dSm}^{-1}, \mathrm{CaCO}_{3}=6.80 \%$, organic matter $=3.12 \%$, available phosphorus and potassium $25.20,404.17 \mathrm{mg} \mathrm{kg}^{-1}$ respectively.

Hillside shrubland: Hillside shrubland has been heavily grazed by goats and sheep throughout the year and contains Phillyrea latifolia, Thymus longicaulis, Paliurus spina-christi, Sarcopoterium spinosum, and Olea oleaster. Grass species such as Dactylis glomerata, Poa pratensis, and Koeleria lobata, and legumes including Medicago lupulina and Trifolium stellatum are also common. The soil is sandy loam, $\mathrm{pH}=7.17, \mathrm{EC}=0.17 \mathrm{dSm}^{-1}, \mathrm{CaCO}_{3}=2.37 \%$, organic matter $=1.37 \%$, available phosphorus and potassium $14.09,167.14 \mathrm{mg} \mathrm{kg}^{-1}$ respectively.

\section{Seed bank sampling}

The seed bank was sampled in August 2007 before fall rains and the onset of germination. Four plots were chosen from each of the six types of grazing lands. Twelve randomly sampled soil cores were obtained from each plot. Cores had a diameter and depth of $10 \mathrm{~cm}$. Soil cores samples were stored in a dark, cold storage area $\left(1^{\circ} \mathrm{C}\right)$ for 6 months. The samples were sorted to eliminate plant fragments and stones. Soil from each plot was combined and 
98

spread onto a plastic tray $(25 \times 50 \times 7 \mathrm{~cm})$ containing $2 \mathrm{~cm}$ of sterile potting soil in February of 2008.

Trays were placed in a greenhouse with natural light and temperature (between 14 and $25^{\circ} \mathrm{C}$ ) and watered frequently. Trays were rotated monthly to a different area of the greenhouse to reduce any effect of placement. Four control trays filled with sterilized potting soil were also randomly placed in the greenhouse to test for contamination. Germination was not observed in control trays.

Seedlings were identified immediately after germination and were counted and removed, or, if they were not immediately identified, transplanted into pots for further growth. After two months, soil samples were carefully turned over to facilitate the emergence of new seedlings (Roberts, 1981). Germination trials lasted for approximately 8 months.

\section{Vegetation survey}

Vegetation was sampled twice by recording the species present in a $0.5 \times 0.5$-m quadrant randomly placed 10 times on the surface of each type of pasture. The first survey was conducted on May 4, 2007, when Mediterranean plants were in the flowering stage. The second survey was conducted on November 4,2007, when plants were in the reproductive stage. Only herbaceous plants germinated in the experiment; thus, the composition of these plants was used exclusively in the vegetation survey.

\section{Data analyses}

To determine species diversity, the Shannon-Wiener index, Simpson index, and Hurlbert's probability of intraspecific encounter were determined. The Pielou index was used to indicate species uniformity (Shannon and Weaver, 1949; Pielou, 1975).

Simpson diversity index: $D=1-\sum P_{i}^{2}$

Shannon-Wiener diversity index: $\mathrm{H}^{\prime}=-\sum P_{i} \ln P_{i}$

Probability of intraspecific encounter:

$P I E=\sum\left[\left(N_{i} / N\right)\left(N-N_{i}\right) /(N-1)\right]$

Pielou evenness index: $J=D /(1-1 / S)$

Where $S=$ species richness, $N_{i}=$ number of the $i$ th species, $N=$ number of all species, and $P_{i}=$ proportion of the $i$ th species.

Soil seed bank density, aboveground vegetation density, and soil properties of grazing lands were compared by a one-way analysis of variance (ANOVA) and Duncan's multiple-range test with $\mathrm{p}=0.05$. All analyses were conducted with MINITAB Release 14.13 (Minitab INC., 1972-2004). Before conducting ANOVA, all data were calculated as the mean \pm standard error.

Seed bank and aboveground vegetation were assessed for similarity using Jaccard's similarity coefficient based on the presence or absence of species (Jaccard, 1912). This coefficient was calculated for all types of vegetation.

$$
C_{i}=a /(a+b+c)
$$

where $a=$ the number of species in sample A and B, $b=$ the number of species present in $\mathrm{A}$ and absent in $\mathrm{B}, c=$ the number of species present in B and absent in A. Jaccard's coefficient ranges from 0 , indicating a lack of mutual species, to 1 , denoting complete concurrence.

\section{Results}

Overall richness and density of the soil seed bank and vegetation

A total of 12,000 seedlings (1,039 in coastal pasture, 2,911 in reseeded pasture, 1,640 in artificial pasture, 2,382 in low shrubland, 1,646 in ungrazed pasture, and 2,382 in hillside shrubland) and 80 species ( 29 in coastal pasture, 33 in reseeded pasture, 23 in artificial pasture, 34 in low shrubland, 33 in ungrazed pasture, and 32 in hillside shrubland) were observed. The largest seed bank was found in reseeded pasture $\left(7,715\right.$ seeds $\left./ \mathrm{m}^{2}\right)$, followed by hillside shrubland, low shrubland $\left(6,314\right.$ seeds $\left./ \mathrm{m}^{2}\right)$, ungrazed pasture $\left(4,363\right.$ seeds $\left.\mathrm{m}^{-2}\right)$, and artificial pasture (4,347 seeds/ $\mathrm{m}^{2}$ ). The smallest seed bank was observed in coastal pasture with 2,755 seeds $/ \mathrm{m}^{2}$. Annual and perennial grasses were predominant in reseeded pasture. However, grasses were rare on artificial pasture and annual forbs were the most common plant $\left(3,105\right.$ plant $\left./ \mathrm{m}^{2}\right)$. Annual forbs were also widespread in hillside shrubland $\left(2,444 \mathrm{plant} / \mathrm{m}^{2}\right)$ but were lowest in reseeded pasture $\left(581 \mathrm{plant} / \mathrm{m}^{2}\right)$. Low shrubland and ungrazed pasture contained the highest level of perennial forbs. The occurrence of legumes on different types of land was not statistically significant (Tab. 1).

A total of 80 species of aboveground vegetation were observed. Of these species, 36 were found in coastal pasture, 29 in reseeded pasture, 25 in artificial pasture, 29

Tab. 1. Nummer of germinated seedlings $/ \mathrm{m}^{2}$ in soil seed bank in different grazing lands of Southern Marmara

\begin{tabular}{ccccccc}
\hline Grazing lands & Annual grasses & Annual forbs & Perennial grasses & Perennial forbs & Legumes & Total \\
\hline Coastal pasture & $701 \pm 279.0 \mathrm{bc}$ & $1,624 \pm 470.0 \mathrm{ab}$ & $247 \pm 121.5 \mathrm{c}$ & $169 \pm 9.19 \mathrm{~b}$ & $167 \pm 20.0$ & $2,755 \pm 96.0 \mathrm{c}$ \\
Reseeded pasture & $4,044 \pm 737.0 \mathrm{a}$ & $581 \pm 183.5 \mathrm{~b}$ & $2,675 \pm 520.5 \mathrm{a}$ & $287 \pm 110.5 \mathrm{~b}$ & $127 \pm 68.8$ & $7,715 \pm 1103.5 \mathrm{a}$ \\
Artificial pasture & $255 \pm 46.9 \mathrm{c}$ & $3,105 \pm 548.5 \mathrm{a}$ & $223 \pm 39.0 \mathrm{c}$ & $342 \pm 116.0 \mathrm{~b}$ & $422 \pm 234.0$ & $4,347 \pm 826.0 \mathrm{bc}$ \\
Lowland shrubland & $1,345 \pm 425.0 \mathrm{bc}$ & $1,624 \pm 307.5 \mathrm{ab}$ & $1,640 \pm 433.5 \mathrm{~b}$ & $1,457 \pm 259.0 \mathrm{a}$ & $247 \pm 84.6$ & $6,314 \pm 829.0 \mathrm{ab}$ \\
Ungrazed pasture & $573 \pm 121.5 \mathrm{bc}$ & $1,879 \pm 500.5 \mathrm{ab}$ & $820 \pm 143.5 \mathrm{bc}$ & $995 \pm 319.5 \mathrm{a}$ & $95 \pm 36.7$ & $4,363 \pm 890.5 \mathrm{bc}$ \\
Hillside shrubland & $1,879 \pm 522.0 \mathrm{~b}$ & $2,444 \pm 626.0 \mathrm{a}$ & $1,481 \pm 259.5 \mathrm{~b}$ & $382 \pm 135.0 \mathrm{~b}$ & $127 \pm 50.3$ & $6,313 \pm 708.5 \mathrm{ab}$ \\
\hline
\end{tabular}

With each column, values (Mean number \pm Standart error) followed by different letters are statistically different at $\mathrm{p}<0.05$. 
in lowland shrubland, 24 in ungrazed pasture, and 20 in hillside shrubland (Tab. 5). The highest density of plants (plant $/ \mathrm{m}^{2}$ ) were observed in ungrazed pasture (155) and the lowest density was found in coastal pasture (131) (Tab. 2). Statistical differences were not significant between annual grasses, annual forbs and legumes in the aboveground vegetation of different types of land. Perennial grasses were lowest in coastal pasture; however, similar levels were observed in other grazing lands. In ungrazed pasture and hillside shrubland, the density of perennial forbs was 15 and 16 plants $/ \mathrm{m}^{2}$, respectively. As shown in Tab. 2, reseeded and artificial pastures displayed the lowest density of perennial forbs. capitata, Gaudinia fragilis, Poa bulbosa, Taeniatherum caput-medusae, Carduus pycnocephalus, Filaga pyramidata, Xeranthemum annuum, Briza sp., Chrysopogon gryllus, Cirsium arvense, Oenanthe silaifolia, Rumex scutatus, Scorzonera cana, Thymus longicaulis, Hippocrepis unisiliquosa, Hymonocarpus circinnatus, Onobrychis sp., and Scorpiurus muricatus were found in vegetation but did not germinate from seed banks (Tab. 3, 4).

Properties of the soil seed bank and aboveground vegetation

The seed banks and aboveground vegetation of artificial pasture had the lowest species richness. The high-

Tab. 2. Number of plants $/ \mathrm{m}^{2}$ in aboveground vegetation in different grazing lands of Southern Marmara

\begin{tabular}{ccccccc}
\hline Grazing lands & Annual grasses & Annual forbs & Perennial grasses & Perennial forbs & Legumes & Total \\
\hline Coastal pasture & $45.8 \pm 6.96$ & $25.2 \pm 7.31$ & $20.9 \pm 4.40 \mathrm{~b}$ & $11.6 \pm 5.35 \mathrm{ab}$ & $27.5 \pm 4.42$ & $131.0 \pm 3.44 \mathrm{c}$ \\
Reseeded pasture & $45.2 \pm 11.65$ & $12.8 \pm 5.46$ & $66.8 \pm 7.59 \mathrm{a}$ & $3.1 \pm 0.94 \mathrm{~b}$ & $22.8 \pm 8.23$ & $150.7 \pm 6.94 \mathrm{ab}$ \\
Artificial pasture & $35.8 \pm 7.33$ & $6.0 \pm 3.74$ & $73.2 \pm 6.27 \mathrm{a}$ & $3.0 \pm 0.63 \mathrm{~b}$ & $28.8 \pm 11.0$ & $146.8 \pm 3.70 \mathrm{abc}$ \\
\hline Lowlan shrubland & $50.8 \pm 16.95$ & $6.7 \pm 7.08$ & $56.8 \pm 29.11 \mathrm{a}$ & $12.7 \pm 3.93 \mathrm{ab}$ & $16.9 \pm 3.63$ & $144.0 \pm 6.56 \mathrm{abc}$ \\
Ungrazed pasture & $65.0 \pm 6.13$ & $8.5 \pm 2.11$ & $57.8 \pm 28.90 \mathrm{a}$ & $15.3 \pm 4.33 \mathrm{a}$ & $7.9 \pm 3.18$ & $154.5 \pm 5.14 \mathrm{a}$ \\
\hline Hillside shrubland & $28.5 \pm 2.88$ & $13.0 \pm 1.21$ & $60.0 \pm 30.04 \mathrm{a}$ & $16.2 \pm 1.68 \mathrm{a}$ & $18.0 \pm 2.16$ & $135.7 \pm 4.25 \mathrm{bc}$ \\
\hline
\end{tabular}

With each column, values (Mean number \pm Standart error) followed by different letters are statistically different at $\mathrm{p}<0.05$

Composition of the soil seed bank and aboveground vegetation

Bromus arvensis, Anagallis arvensis, Dactylis glomerata, Poa pratensis, and Galium sp. were germinated from soil seed banks of all grazing lands. Germinating seeds of Aira coryophyllea, Bromus hordeceus, Gaudinia fragilis, Hordeum marinum, Polypogon monspeliensis, Lagurus ovatus, Geranium dissectum, Silene gallica, Cyperus capitatus, Astragalus homosus, and Trifolium repens were found exclusively in coastal pasture. Bromus tectorum, Phalaris paradoxa, Eryngium creticum, and Medicago rigidula germinated from seed banks of reseeded pasture, while Solanum nigrum, Anchusa azurea, Cichorium intybus, and Prunella laciniata were germinated from seed banks of lowland shrubland. Seeds of Fumoria densifolia, Turgenia latifolia, Carlina corymbosa, Centaurium erythraea, Foeniculum vulgare, and Verbascum sp. germinated from ungrazed pasture and Filago pyramidata, Mercurialis annua, Velezia quadridentata, Dianthus leptopetalus, Salvia verbenacea, Teucrium scordium, and Trifolium stellatum seeds germinated from soil obtained from hillside shrubland (Tab. 3). Polypogon monspeliensis, Trchynia distochya, Vulpia ciliata, Euphorbia helioscopia, Kickxia elatina, Mercurialis annua, Ranunculus ficaria, Solanum nigrum, Sonchus oleracus, Alchemilla mollis, Achusa azurea, Bellis perennis, Carlina corymbosa, Cichorium intybus, Foeniculum vulgare, Prunella laciniata, and Teucrium scardium germinated exclusively from seed banks and were not found in aboveground vegetation. On the other hand, Aegilops umbellulata, Echinaria est number of species was found in low shrubland (34), reseeded pasture (33), ungrazed pasture (33) and hillside shrubland (32). Coastal pasture had the highest number of species (36) in aboveground vegetation; however, there were less species in seed banks of coastal pasture and artificial pasture compared to aboveground vegetation. Alternatively, other types of grazing lands contained more species in seed banks than in vegetation. The highest seed bank diversity $(\mathrm{D}=0.958$ and PIE $=0.957)$ was observed in lowland shrubland, while diversity was the lowest in the seed bank and aboveground vegetation of artificial pasture $(\mathrm{D}=0.842,0.854$ and PIE $=0.838,0.839$, respectively $)$. The highest diversity (D and PIE) in aboveground vegetation was found in coastal pasture. Artificial pasture displayed the lowest uniformity in both the seed bank and vegetation $(\mathrm{J}=0.881,0.890)$. The highest value of uniformity was found in the seed bank of lowland shrubland $(\mathrm{J}$ $=0.987)$ and in vegetation of coastal pasture $(\mathrm{J}=0.961)$ (Tab. 5).

\section{Similarity and relationship between soil seed bank and} aboveground vegetation

Similarity between soil seed bank and aboveground vegetation was strong. The values of Jaccord's coefficient of community ranged from 0.411 to 0.676 (with a mean of 0.518) (Tab. 6). Fluctuations in similarity were observed between different grazing lands in vegetation quadrants and seed banks. The similarity between different types of aboveground vegetation varied between 0.100 and 0.410 
100

Tab. 3. Characteristics of the soil seed bank (means, seeds $/ \mathrm{m}^{2}$ ) of the grazing lands

\begin{tabular}{|c|c|c|c|c|c|c|}
\hline Species & Coastal pasture & Reseeded pasture & Artificial pasture & Lowland shrubland & Ungrazed pasture & Hillside shrubland \\
\hline \multicolumn{7}{|l|}{ Annual grasses } \\
\hline Alopecurus creticus & 71.65 & & & 151.27 & & \\
\hline Aira caryophyllea & 55.73 & & & & & \\
\hline Avena barbata & & 310.50 & 71.65 & 159.23 & 111.46 & 350.31 \\
\hline Avena clauda & 119.42 & 230.89 & & & 47.77 & \\
\hline Bromus arvensis & 55.73 & 485.66 & 63.69 & 318.47 & 127.38 & 310.50 \\
\hline Bromus hordeaceus & 87.57 & & & & & \\
\hline Bromus sterilis & & 509.55 & 63.69 & 278.66 & & 103.50 \\
\hline Bromus tectorum & & 461.78 & & & & \\
\hline Cynosurus echinatus & & & & & 135.34 & 230.89 \\
\hline Dasypyrum villosum & & 374.20 & 39.80 & 254.77 & & 175.15 \\
\hline Gaudinia fragilis & 39,80 & & & & & 39.80 \\
\hline Hordeum marinum & 87.57 & & & & & \\
\hline Hordeum spotaneum & & & & & 135.34 & 358.27 \\
\hline Phalaris paradoxa & & 318.47 & & & & \\
\hline Phleum subulatum & 79.61 & 103.50 & 15.92 & & & \\
\hline Polypogon monspeliensis & 63.69 & & & & & \\
\hline Lagurus ovatus & 39.80 & & & & & 135.34 \\
\hline Trachynia distachya & & 1249.99 & & 183.12 & & 143.31 \\
\hline Vulpia ciliata & & & & & 15.92 & 31.84 \\
\hline \multicolumn{7}{|l|}{ Annual forbs } \\
\hline Anagallis arvensis & 135.34 & 214.96 & 222.92 & 246.81 & 31.84 & 135.34 \\
\hline Anthemis arvensis & 31.84 & 15.92 & & & 7.96 & \\
\hline Arenaria leptoclados & & & & & 95.54 & $1,289.80$ \\
\hline $\begin{array}{l}\text { Centaurium } \\
\text { tenuiflorum }\end{array}$ & 55.73 & 39.80 & & 207.00 & 31.84 & 525.47 \\
\hline Chenopodium glaucum & 95.54 & & & 159.23 & & 7.96 \\
\hline Crepisfoetida & 143.31 & 15.92 & 55.73 & 39.80 & & \\
\hline Crepispulchra & & 39.80 & & 310.50 & 119.42 & \\
\hline Crepis zacintha & & 47.77 & $1,122.60$ & & 15.92 & 31.84 \\
\hline Filago pyramidata & & & & & & 183.12 \\
\hline Fumaria densiflora & & & & & 613.05 & \\
\hline Geranium dissectum & 103.50 & & & & & \\
\hline Hedypnois cretica & & 15.92 & & 79.61 & & \\
\hline Kickxia elatine & & 79.61 & 31.84 & & & \\
\hline Lactuca saligna & & & 31.84 & 47.77 & & \\
\hline Mercurialis annua & & & & & & 23.88 \\
\hline Picnomon acarna & & 23.88 & 175.15 & & & \\
\hline Ranunculus ficaria & & & & & 501.59 & 23.88 \\
\hline Silene gallica & 207.00 & & & & & \\
\hline Solanum nigrum & & & & 191.08 & & \\
\hline Sonchus oleraceus & & 15.92 & & & & \\
\hline Stellaria media & 573.24 & & & 111.46 & & \\
\hline Torilis arvensis & 238.85 & 47.77 & $1,202.22$ & 230.89 & 453.81 & \\
\hline Turgenia latifolia & & & & & 7.96 & \\
\hline Velezia quadridentata & & & & & & 31.84 \\
\hline Veronica arvensis & 39.80 & 23.88 & 262.73 & & & 191.08 \\
\hline \multicolumn{7}{|l|}{ Perennial grasses } \\
\hline Cyperus capitatus & 23.88 & & & & & \\
\hline Dactylis glomerata & 119.42 & 1138.53 & 71.65 & 509.55 & 445.85 & 764.32 \\
\hline Koeleria lobata & & & & 398.08 & & 294.58 \\
\hline Lolium perenne & & 907.63 & 103.50 & 366.24 & 222.9 & 183.12 \\
\hline
\end{tabular}




\begin{tabular}{|c|c|c|c|c|c|c|}
\hline Species & Coastal pasture & Reseeded pasture & Artificial pasture & Lowland shrubland & Ungrazed pasture & Hillside shrubland \\
\hline Poapratensis & 103.50 & 628.97 & 47.77 & 366.24 & 151.27 & 238.85 \\
\hline \multicolumn{7}{|l|}{ Perennial forbs } \\
\hline Alchemilla mollis & & & 23.88 & & 23.88 & \\
\hline Anchusa azurea & & & & 191.08 & & \\
\hline Bellis perennis & & 23.88 & & & 71.65 & \\
\hline Carlina corymbosa & & & & & 55.73 & \\
\hline Centaurium erythraea & & & & & 39.80 & \\
\hline Cichorium intybus & & & & 103.50 & & \\
\hline Dianthus leptopetalus & & & & & & 15.92 \\
\hline Eryngium creticum & & 15.92 & & & & \\
\hline Euphorbiasp. & & & & 79.61 & 39.80 & \\
\hline Foenicum vulgare & & & & & 135.34 & \\
\hline Galium heldreichii & 15.92 & 183.12 & 119.42 & 15.92 & 246.81 & 294.58 \\
\hline Linum nodiflorum & & 63.69 & & 278.66 & & \\
\hline Plantago lagopus & & & & & 119.42 & 39.80 \\
\hline Plantago lanceolata & & & & 326.43 & 39.80 & \\
\hline Prunella laciniata & & & & 127.38 & & \\
\hline Ranunculus repens & & & & 95.54 & 183.12 & \\
\hline Salvia verbenaca & & & & & & 7.96 \\
\hline Scolymus hispanicus & & & 199.04 & 238.85 & & \\
\hline Teucrium scordium & & & & & & 23.88 \\
\hline Verbascum sp. & & & & & 39.80 & \\
\hline \multicolumn{7}{|l|}{ Legumes } \\
\hline Astragalus hamosus & 79.61 & & & & & \\
\hline Lotus corniculatus & & & 318.47 & & 47.77 & \\
\hline Medicago lupulina & 15.92 & 31.84 & & 23.88 & & \\
\hline Medicago minima & & 39.80 & 39.80 & 31.84 & & 79.61 \\
\hline Medicago rigudula & & 15.92 & & & & \\
\hline Trifolium campestre & & & & 95.54 & 31.84 & \\
\hline Trifolium pratense & & 23.88 & 31.84 & 47.77 & & \\
\hline Trifolium repens & 55.73 & & & & & \\
\hline Trifolium resupinatum & & 15.92 & 31.84 & 47.77 & 15.92 & \\
\hline Trifolium stellatum & & & & & & 23.88 \\
\hline Trifolium tomentosum & 15.92 & & & & & 23.88 \\
\hline Total & 2,755 & 7,715 & 4,347 & 6,313 & 4,363 & 6,313 \\
\hline
\end{tabular}

(Tab. 6: v). Between different types of seed banks, similarity ranged from 0.173 to 0.459 (Tab. 6: s). The degree of similarity in seed banks was moderately stronger than in vegetation. The weakest similarity was found in the vegetation of hillside shrubland and coastal pasture. The strongest similarity was observed in the seed bank and vegetation of reseeded and artificial pasture. In seed banks, the weakest similarity was observed between ungrazed and coastal pasture.

\section{Discussion}

Reseeded pasture was rich with germinated seeds. Seeds of herbaceous species were produced in between $\mathrm{Pa}$ liurus spina-christi plants, which had been growing for a long period of time and prevented grazing. After removing shrubs, reseeding with legumes and grass led to an increase in the number of seeds in the seed bank. Reseeded pasture has productive soils with the least amount of erosion due to a low slope. The species diversity of germinative seeds increased with increasing soil fertility (Staff et al., 1987).

Shrublands were rich in germinating seeds; specifically, low shrubland displayed the highest species richness, diversity and uniformity. When compared to other types of shrublands, lowland shrubland experienced the least water stress and little to no erosion due to a lack of slopes. Animals were not able to access herbaceous vegetation between shrubs; thus, plants produced seeds even under heavy grazing. Seeds in low shrublands disperse by many mechanisms: small seeds dispersed by wind, animals and overflow (Harper, 1977; Grant, 1983).

In ungrazed pasture, less germination occurred compared to other types of shrubland. Similarly, Bakoğlu et al. (2009) reported more germination in grazed land com- 
102

Tab. 4. Characteristics of aboveground vegetation (means, plants $/ \mathrm{m}^{2}$ ) of the grazing lands

\begin{tabular}{|c|c|c|c|c|c|c|}
\hline Species & $\begin{array}{l}\text { Coastal } \\
\text { pasture }\end{array}$ & $\begin{array}{c}\text { Reseeded } \\
\text { pasture }\end{array}$ & $\begin{array}{c}\text { Artificial } \\
\text { pasture }\end{array}$ & $\begin{array}{l}\text { Lowland } \\
\text { shrubland }\end{array}$ & $\begin{array}{l}\text { Ungrazed } \\
\text { pastured }\end{array}$ & $\begin{array}{c}\text { Hillside } \\
\text { shrubland }\end{array}$ \\
\hline \multicolumn{7}{|l|}{ Annual grasses } \\
\hline Aegilops umbellulata & & 4.37 & 5.06 & 9.07 & & 7.47 \\
\hline Alopecurus creticus & 0.13 & & & & & \\
\hline Aira caryophyllea & 5.53 & & & & & \\
\hline Avena barbata & & & 1.68 & 7.35 & 6.45 & 18.05 \\
\hline Avena clauda & 12.29 & 0.44 & & & 10.58 & \\
\hline Bromus arvensis & 5.18 & 8.99 & 2.09 & 13.92 & 12.65 & 2.98 \\
\hline Bromus hordeceus & 2.71 & & & & & \\
\hline Bromus sterilis & & 5.61 & 3.62 & 5.24 & & \\
\hline Bromus tectorum & & 0.36 & & & & \\
\hline Cynosurus echinatus & & & 5.26 & & 1.30 & \\
\hline Dasypyrum villosum & & 6.61 & 3.48 & & & \\
\hline Echinaria capitata & & & 0.78 & & & \\
\hline Gaudinia fragilis & 5.49 & & & & & \\
\hline Hordeum marinum & 5.36 & & & & & \\
\hline Hordeum spotaneum & & 10.16 & 5.46 & 15.22 & 34.02 & \\
\hline Phalaris paradoxa & & 0.75 & & & & \\
\hline Phleum subulatum & 0.32 & 2.75 & 4.31 & & & \\
\hline Poabulbosa & 1.98 & 4.91 & 4.07 & & & \\
\hline Lagurus ovatus & 6.87 & & & & & \\
\hline Taeniatherum caput-medusae & & 0.25 & & & & \\
\hline \multicolumn{7}{|l|}{ Annual forbs } \\
\hline Anagallis arvensis & 3.92 & 4.05 & 2.15 & & 0.65 & 3.37 \\
\hline Anthemis arvensis & 6.75 & & & & 1.08 & \\
\hline Arenaria leptoclados & & & & & 1.33 & 2.17 \\
\hline Carduuspycnocephalus & & & & 1.85 & & \\
\hline Centaurium teniflorum & 1.88 & & & 0.70 & & 1.12 \\
\hline Chenopodium glaucum & 2.13 & & & 1.05 & & \\
\hline Crepisfoetida & 2.20 & & & 0.21 & & \\
\hline Crepispulchra & & 0.04 & 0.08 & 1.99 & 0.97 & \\
\hline Crepis zacintha & 0.19 & 0.08 & 0.12 & & 0.90 & 1.63 \\
\hline Filago pyramidata & & & & & & 1.41 \\
\hline Fumaria densiflora & & & & & 1.57 & \\
\hline Geranium dissectum & 1.31 & 3.06 & 1.26 & & & \\
\hline Hedypnois cretica & & 3.07 & & & & \\
\hline Lactuca saligna & & & 2.39 & & & \\
\hline Picnomon acarna & & 2.53 & & & & \\
\hline Silene gallica & 1.35 & & & & & \\
\hline Stellaria media & & & & 0.21 & & \\
\hline Torilis arvensis & 1.89 & & & & 1.80 & \\
\hline Turgenia latifolia & & & & & 0.22 & \\
\hline Xeranthemum annum & 3.58 & & & & & \\
\hline Velezia quadridentata & & & & 0.73 & & 1.28 \\
\hline Veronica arvensis & & & & & & 2.02 \\
\hline \multicolumn{7}{|l|}{ Perennial grasses } \\
\hline Brizasp. & 2.32 & & & & & \\
\hline Chrysopogon gryllus & 1.11 & & & & & \\
\hline Cyperus capitatus & 2.80 & & & & & \\
\hline Dactylis glomerata & 6.42 & 10.88 & 7.84 & 8.19 & 21.10 & 12.07 \\
\hline Koeleria lobata & & & & 18.00 & & 20.62 \\
\hline
\end{tabular}




\begin{tabular}{|c|c|c|c|c|c|c|}
\hline Species & $\begin{array}{l}\text { Coastal } \\
\text { pasture }\end{array}$ & $\begin{array}{c}\text { Reseeded } \\
\text { pasture }\end{array}$ & $\begin{array}{c}\text { Artificial } \\
\text { pasture }\end{array}$ & $\begin{array}{l}\text { Lowland } \\
\text { shrubland }\end{array}$ & $\begin{array}{l}\text { Ungrazed } \\
\text { pastured }\end{array}$ & $\begin{array}{c}\text { Hillside } \\
\text { shrubland }\end{array}$ \\
\hline Lolium perenne & & 45.20 & 55.68 & 14.77 & 16.86 & 10.45 \\
\hline Poapratensis & 8.33 & 10.72 & 9.65 & 15.90 & 19.87 & 16.86 \\
\hline \multicolumn{7}{|l|}{ Perennial forbs } \\
\hline Centaurium erythraea & & & & & 4.83 & \\
\hline Cirsium arvense & 0.27 & & 0.90 & 1.12 & & \\
\hline Dianthus leptopetalus & 6.09 & & & & & \\
\hline Eryngium creticum & 0.12 & & & 2.77 & & \\
\hline Galium heldreichii & & 0.51 & 0.18 & 1.74 & 1.40 & 2.09 \\
\hline Linum nodiflorum & & & & & & 2.61 \\
\hline Oenanthe sileifolia & & 1.00 & & & & \\
\hline Plantago lagopus & & & 1.18 & & & 3.91 \\
\hline Plantago lanceolata & & 1.61 & & 5.97 & & \\
\hline Ranunculus repens & & & & 0.44 & 3.52 & \\
\hline Rumex scutatus & 4.87 & & & & & \\
\hline Salvia verbenaca & 0.30 & & & 0.70 & & \\
\hline Scolymus hispanicus & & & & & & 2.41 \\
\hline Scorzonera cana & & & 0.75 & & & \\
\hline Thymus longicaulis & & & & & & 5.18 \\
\hline Verbascum sp. & & & & & 5.57 & \\
\hline \multicolumn{7}{|l|}{ Legumes } \\
\hline Astragalus hamosus & 6.52 & & & & 1.27 & \\
\hline Hippocrepis unisiliquosa & & & & 3.13 & & \\
\hline Hymonocarpus circinnatus & & & & & 1.61 & \\
\hline Lotus corniculatus & & & 8.26 & & & \\
\hline Medicago lupulina & 9.02 & 11.85 & & 0.57 & & \\
\hline Medicago minima & & 1.03 & 1.29 & 4.03 & & 7.48 \\
\hline Medicago rigudula & & 3.18 & & & & \\
\hline Onobrchissp. & & & & 2.00 & & \\
\hline Scorpiurus muricatus & & 1.49 & 1.45 & 3.16 & & \\
\hline Trifolium campestre & 1.92 & & 0.78 & 2.25 & 4.91 & \\
\hline Trifolium pratense & & 0.31 & 4.76 & 0.82 & & \\
\hline Trifolium repens & 1.53 & & & & & \\
\hline Trifolium resupinatum & 6.87 & 4.94 & 9.16 & 0.97 & 0.12 & \\
\hline Trifolium stellatum & & & 3.14 & & & 10.57 \\
\hline Trifolium tomentosum & 1.64 & & & & & \\
\hline Total & 131,19 & 150,75 & 146,83 & 144,07 & 154,58 & 135,75 \\
\hline
\end{tabular}

pared to ungrazed land. Grazing allows seeds to become rate was observed in Hordeum spotaneum, Centaurium erburied in the soil (Altın et al., 2005) and grazing animals ythraea due to less seed burial and more seed damage.

cause a decrease in the number of seed predators (birds, The number of seeds that germinated in artificial pasrodents, etc.) (Gökkuş and Koç, 2001). Despite a higher ture was low. These lands also displayed the lowest speseed production in ungrazed land, a lower germination cies richness, diversity and uniformity. Artificial pasture

Tab. 5. Species richness, diversity, and uniformity in soil seed bank and vegetation (Soil seed bank/ aboveground vegetation)

\begin{tabular}{cccccc}
\hline Grazing lands & $\begin{array}{c}\text { Species } \\
\text { richness }(S)\end{array}$ & Simpson index $(D)$ & Shannon index $\left(H^{\prime}\right)$ & Hurlbert's PIE & Pielou index $(J)$ \\
\hline Coastal pasture & $28 / 36$ & $0.924 / 0.934$ & $2.968 / 3.053$ & $0.903 / 0.955$ & $0.958 / 0.961$ \\
Reseeded pasture & $33 / 29$ & $0.913 / 0.884$ & $2.753 / 2.596$ & $0.911 / 0.880$ & $0.941 / 0.916$ \\
Artificial pasture & $23 / 25$ & $0.842 / 0.854$ & $2.335 / 2.510$ & $0.838 / 0.839$ & $0.881 / 0.890$ \\
Lowland shrubland & $34 / 29$ & $0.958 / 0.908$ & $2.306 / 2.718$ & $0.957 / 0.899$ & $0.987 / 0.940$ \\
Ungrazed pasture & $33 / 24$ & $0.929 / 0.886$ & $2.968 / 2.373$ & $0.929 / 0.880$ & $0.958 / 0.929$ \\
Hillside shrubland & $32 / 20$ & $0.914 / 0.887$ & $2.850 / 2.506$ & $0.915 / .0907$ & $0.944 / 0.929$ \\
\hline
\end{tabular}


Tab. 6. Jaccard's similarity coefficient among different types of soil seed bank and vegetation

\begin{tabular}{ccccccc}
\hline Grazing lands & $\begin{array}{c}\text { Coastal } \\
\text { pasture }\end{array}$ & $\begin{array}{c}\text { Reseeded } \\
\text { pasture }\end{array}$ & $\begin{array}{c}\text { Artificial } \\
\text { pasture }\end{array}$ & $\begin{array}{c}\text { Lowland } \\
\text { shrubland }\end{array}$ & $\begin{array}{c}\text { Ungrazed } \\
\text { pasture }\end{array}$ & $\begin{array}{c}\text { Hillside } \\
\text { shrubland }\end{array}$ \\
\hline Coastal pasture & $0.600 s v$ & $0.207 v$ & $0.150 v$ & $0.226 v$ & $0.220 v$ & $0.100 v$ \\
Reseeded pasture & $0.270 s$ & $0.512 s v$ & $0.410 v$ & $0.295 v$ & $0.261 v$ & $0.166 v$ \\
Artificial pasture & $0.219 s$ & $0.459 s$ & $0.411 s v$ & $0.350 v$ & $0.289 v$ & $0.216 v$ \\
Lowland shrubland & $0.240 s$ & $0.425 s$ & $0,390 s$ & $0.465 s v$ & $0.232 v$ & $0.225 v$ \\
Ungrazed pasture & $0.173 s$ & $0.294 s$ & $0.272 s$ & $0.288 s$ & $0.676 s v$ & $0.194 v$ \\
Hillside shrubland & $0.224 s$ & $0.250 s$ & $0.250 s$ & $0.245 s$ & $0.274 s$ & $0.444 s v$ \\
\hline
\end{tabular}

v) Similarity among different types of vegetation; s) Similarity among different types of seed bank; $s v$ ) Similarity between seed bank and aboveground vegetation of the same type

originated as farmland and was transformed into pasture by reseeding; thus, these lands have a low number of seeds in the seed bank. In fact, annual forbs and weeds were most often germinated in artificial pasture. These results agree with the observations of Gokkus (1994), Walker $e t$ al. (2004) and Zhan et al. (2007), who found that annual forbs and grasses were abundant in abandoned farmlands. Perennials were not able to develop or produce seeds in farmlands due to seasonal plowing; thus, annuals and weeds produced seeds intensively.

Coastal pasture had the lowest number of germinated seeds and vegetation on these lands (Tab. 3). This may be due to the texture of coastal soils: buried seeds were able to resurface from the sandy soil and seeds left on the soil surface were eaten by insects such as ants and beetles and small mammals (Thompson, 1987). Similarly, Staff et al. (1987) found that less seeds were germinated from sandy loams. In coastal pasture, species richness was higher in vegetation than in the seed bank. This result indirectly suggests that asexual reproduction was the primary method of reproduction in coastal grassland. Similar results have been obtained in steppe ecosystems (Zhan et al., 2007). Thus, the preservation of perennial vegetation may play a more significant role in grassland recovery than soil seed banks.

The most germinated species in all grazing lands were annuals. Research has shown that annuals are a major component of Mediterranean grasslands (Marcelo et al., 2003). The grazing of Mediterranean grasslands can have a large impact on vegetation (Montalvo et al., 1993; Seligman, 1996; Lavorel et al., 1999; Sternberg et al., 2000); however, the soil seed bank may buffer the impact of differences in inter-annual grazing (Russi et al., 1992; Ortega et al., 1997). It is generally assumed that Mediterranean annuals show adaptive responses to unpredictable environments by producing dormant seeds that persist during periods of limited resources (Shmida and Ellner, 1984; Thompson, 1992; Lavorel et al., 1993; Perevolotsky and Seligman, 1998). Thus, a persistent soil seed bank acts as a long-term refuge for annual plant populations in variable environments typical of the Mediterranean region (Kigel, 1995).

With the exclusion of coastal pasture, seed banks of grazing land contained more species than aboveground vegetation. This is expected in heavily grazed pastures be- cause plants are removed by grazing but seeds remain in the soil due to dormancy.

Many studies have been conducted on the similarity of seed banks and aboveground vegetation. Low similarities were observed between the seed bank and aboveground vegetation in most studies involving grasslands dominated by perennial grasses (Rabinowitz, 1981; Archibold, 1981; Schenkeveld and Verkaor, 1984; Thomson, 1986; Fischer, 1987; Millberg, 1995; Bakkler et al., 1996). These discrepancies were explained by the minor contribution of dominant perennial grassland species to seed banks. In general, perennial grasses have low seed production because they alternate between sexual reproduction and vegetative forms and their seeds persist in the soil for short periods of time (Touzard et al., 2002).

The strongest similarity between vegetation and seed bank was observed in coastal and ungrazed pastures. Annual grasses and forbs commonly grow in coastal pasture and water stress often occurs due to the presence of sandy soils. This leads to rapid seed production by annuals and results in increased similarity (Peco et al., 1998). Plants in ungrazed pasture produce seeds in vast quantity. Since there is no grazing pressure, plants do not disappear from the vegetation. Due to the fact that seeds on the aboveground vegetation are buried in the soil, similarity between the soil seed bank and vegetation increases (Grime, 1979). The weakest similarity between vegetation was observed in hillside shrubland and coastal pasture. Sandy soil in coastal pasture results in unique plant species and the weakest similarity.

The strongest similarity was observed in seed banks and vegetation of reseeded and artificial pasture. These pastures are located close to each other and possess similar soils. Although the use of reseeded and artificial pastures is different, their characteristics are quite similar. This result indicates that soil properties have an effect on vegetation type.

\section{Conclusions}

The grazing lands of Southern Marmara are under heavy grazing pressure and shrublands play a crucial role in species richness and the number of seeds that germinate. 
A decrease in grazing pressure and reseeding with desired plants will improve the conditions of grazing lands.

\section{Acknowledgements}

We wish to thank Dr. Ersin Karabacak (Canakkale Onseliz Mart University) for plant identification.

\section{References}

Altın M, Gokkus A, Koc A (2005). Range and Meadow Improvement and Development. T.C. The Ministry of Agriculture and Rural Affairs, Republic of Turkey.

Archibold OW (1981). Burial viable propagules in native prairie and adjacent agricultural sites in central Saskatchewan. Can J Bot 59:701-706.

Bakker JP (1989). Nature Management by Grazing and Cutting. Kluwer Academic Publishers, Dordrecht.

Bakker JP, Bakker ES, Rosen E, Verweij GL, Bekker RM (1996). Soil seed bank composition along a gradient from dry avlar grassland to Juniperus shrubland. J Veg Sci 7:165-176.

Bakoglu A, Bagci E, Erkovan HI, Koc A, Kocak A (2009). Seed stocks of grazed and ungrazed rangelands on Palandoken Mountains of Eastern Anatolia. J of Food, Agriculture and Environment 7(3,4):674-678.

Bochet E, Rubio JL, Poesen J (1999). Modified topsoil islands within patchy Mediterranean in SE Spain. Catena 38:2344.

Gökkuş A (1994). Secondary succession in the abandoned rangelands. Ataturk University Publication No: 787, Erzurum, p. 61.

Gokkus A, Koc A (2001). Range Management. Ataturk University, Agriculture Faculty Publication No . 228.

Grant JD (1983). The activities of earthworms and the fates of seeds, p. 107-122. In: Satchell JE (Ed.). Earthworm ecology. Chapman and Hall, London.

Grime JP (1979). Plant Strategies and Vegetation Processes. Chichester, John Wiley and Sons.

Grubb PJ (1977). The maintenance of species-richness in plant communities:the importance of the regeneration niche. Biol Rev 52:107-145.

Harper JL (1977). Population Biology of Plants. Academic press, London, p. 892.

Jaccard P (1912). The distribution of the flora of the alpine zone. New Phytology 11:37-50.

Jutila HM (1998). Seed banks of grazed and ungrazed Baltic seashore meadows. J of Vegetation Sci 9:395-408.

Kigel J (1995). Seed germination in arid and semiarid regions, $p$. 645-699. In: Kigel J, Galili G (Eds.). Seed Dvelopment and Germination. Marcel Dekker, NY, USA.

Lavorel S, Debussche M, Lebreton JD, Lepart J (1993). Seosanal patterns in the seed bank of Mediterranean old-fields. Oikos 67:114-128.

Lavorel S, Rochette C, Lebreton JD (1999). Functional groups
105 for response to disturbance in Mediterranean old-fields. Oikos 84:480-498.

Leck MA, Parker YT, Simpson RL (1989). Ecology of Soil Seed Banks. Academic Press, New York.

Marcelo S, Mario G, Avi P, Jaime K (2003). Effects of grazing on soil seed bank dynamics: An approach with functional groups. J of Vegetation Sci 14:375-386.

Mayor MD, Bo'o RM, Pela'ez DV, Elia OR (2003). Seasonal variation of the soil seed bank of grasses in central Argentina as related to grazing and shrub cover. J of Arid Environments 53:467-477.

Milberg P (1995). Soil seed bank after eighteen years of succession from grassland to forest. Oikos 72:3-13.

Montalvo J, Casado MA, Levassor C, Pineda FD (1993). Species-diversity patterns in Mediterranean grasslands. J Veg Sci 4:213-222.

Navie SC, Cowley RA, Rogers RW (1996). The relationship between distance from water and the soil seed bank in a grazed semi-arid subtropical rangeland. Australian Journal of Botany 44:421-431.

O'Connor TG, Pickett GA (1992). The influence of grazing on seed production and seed banks of some African savanna grasslands. J of Applied Ecology 29:247-260.

Ortega M, Levassor C, Peco B (1997). Seasonal dynamics of Mediterranean pasture seed banks along environmental gradients. Biogeography 24:177-195.

Ozaslan-Parlak A, Gokkus A, Hakyemez BH, Baytekin $H$ (2011). Forage yield and quality of kermes oak and herbaceous species throughout a year in Mediterranean zone of western Turkey. International Journal of Food, Agriculture and Environment 9(1):510-515.

Papachiristou TG, Nastis AS, Mathur R, Hutchings MR (2003). Effect of physical and chemical plant defences on herbivory: implications for Mediterranean shrubland management. Basic Appl Ecollogy 4:395-403.

Papachristou TG (1994). Foraging behaviour and nutrition of goats grazing on shrublands of Greece. In: Gordon LJ and Rubino R (Eds.). Grazing Behaviour of Goats and Sheep, Cahiers Options Mediterranean 5:83-90.

Peco B, Ortega M, Levassor C (1998). Similarity between seed bank and vegetation in Mediterranean grassland: a predictive model. J Veg Sci 9:815-828.

Perevolotsky A, Seligman NG (1998). Role of grazing in Mediterranean rangeland ecosystems-Inversion of a paradigm. BioScience 48:1007-1017.

Pielou EC (1975). Ecology Diversity. New York: John Wiley and Sons Inc.

Rabinowitz D (1981). Buried viable seed in a North American tall-grass prairie: The resemblance of their abundance and composition to dispersing seeds. Oikos 36:191-195.

Raunkiaer C (1934). The Life Forms of Plants and Statistical Plant Geography. Oxford Univ. Press, London.

Roberts HA (1981). Seed banks in soils. Advanced Applied 
106

Biology 6:1-55.

Russi L, Cocks PS, Roberts EH (1992). Seed bank dynamics in a Mediterranean grassland. J Appl Ecol 29:763-771.

Schenkeveld AJ, Verkaar HJ (1984). The ecology of short-lived forbs in chalk grasslands: distribution of germinative seeds and its significance for seedling emergence. J Biogeogr 11:251-260

Seligman NG (1996). Management of Mediterranean grasslands, p. 359-392. In: Hodgson J, Illius AW (Eds.). The Ecology and Management of Grazing Systems. CAB International, Wallingford, UK.

Shannon CE, Weaver W (1949). The mathematical theory of communication. Illinois University Press.

Shmida A, Ellner S (1984). Coexistence of plant species with similar niches. Vegetatio 58:29-55.

Staaf H, Jonsson M, Olsen LG (1987). Buried germinative seeds in mature beech forests with different herbaceous vegetation and soil types. Holarctic Ecology 10:268-277.

Sternberg M, Gutman M, Perevolotsky A, Kigel J (2003). Effects of grazing on soil seed bank dynamics: an approach with functional groups. J of Vegetation Sci 14:375-386.

Sternberg M, Gutman M, Perevolotsky A, Ungar ED, Kigel J (2000). Vegetation response to grazing management in a Mediterranean herbaceous community: a functional group approach. J Appl Ecol 37:224-237.

Tallowin JRB (1996). Effects of inorganic fertilizers on flowerrich hay meadows: a review using a case study on the Somerset Levels, UK. Grassland and Forage Abstracts 66:147-152.

Thompson K (1986). Small-scale heterogeneity in the seed bank of an acidic grassland. J Ecol 74:733-738.

Thompson K (1987). Seeds and Seed banks, p. 23-34. In: Rorison IH, Grime JP, Hunt R, Hendry GAF, Lewis DH (Eds.). Frontiers of Comparative Plant Ecology. New Phytologist 106 (Suppl.).
Thompson K (1992). The functional ecology of seed banks, p. 231-258. In: Fener M (Ed.). Seeds. The Ecology of Regeneration in Plant Communities. CAB International, Wallingford, UK.

Tölü C, Yurtman İY, Baytekin H, Savaş T (2007). Grazing preferences of three goat genotypes grazed on wheat forage and natural shrubland. The V Symposium of Agriculture, Veterinary, Forestry and Biotechnology, 18-20 Oct. Travnik/ Vlasic-Bosnia and Herzegovina.

Türkeş M, Sümer UM, Demir İ (2002). Re-evaluation of trends and changes in mean, maximum and minimum temperatures of Turkey for the period 1929-1999. International Journal of Climatology 22:947-977.

Walker KJ, Stevens DA, Stevens PA, Mountford JO, Manchester S, Pywell RF ( 2004). The restoration and re-creation of species-rich lowland grassland on land formerly managed for intensive agriculture in the UK. Biological Conservation 119:1-18.

Wisheu IC, Keddy PA (1991). Seed banks of a rare wetland plant community: distribution patterns and effects of human-induced disturbance. J Vegetation Sci 2:181-188.

Yilmaz KT (1996). Natural Plants of Mediterrenean. Çukurova University Faculty of Agriculture Publication No. 141, p. 179.

Yilmaz O (1993). Maquis. Ankara University, Agriculture Faculty Publication No. 1326, p. 60.

Zhan X, Li L, Cheng W (2007). Restoration of Stipa krylovii steppes in Inner Mongolia of China: Assess seed banks and vegetation composition. J of Arid Environments 68:298307. 